\title{
The Symposium on Overcoming Modernity and Discourse in Wartime Japan
}

\author{
JOHN W. M. KRUMMEL*
}

Kolokvium o překonání modernity jako ukázka japonského diskurzu za druhé světové války

\begin{abstract}
The symposium on overcoming modernity (kindai no chōkoku) that took place in Tokyo in 1942 has been much commented upon, but later critics have tended to over-emphasize the wartime political context and the ideological connection to Japanese ultra-nationalism. Closer examination shows that the background and the actual content of the discussion were more complicated. The idea of overcoming modernity had already appeared in debates among Japanese intellectuals before the war, and was always open to different interpretations; it could indicate Japanese ambitions to move beyond Western paradigms of modernity, but in other cases it referred to more radical visions of alternatives to modernity as such. Some versions linked up with Western critiques of existing modernity, including traditionalist as well as more future-oriented ones. These differentiations are evident in the symposium, and associated with diverse schools of thought. An important input came from representatives of the Kyoto school, the most distinctive current in twentieth-century Japanese philosophy. Despite the suppression of Marxist thought, the background influence of the unorthodox Marxist thinker Miki Kiyoshi was significant. Another major contribution came from the group known as the Japan Romantic School, active in literature and literary criticism. Other intellectuals of widely varying persuasions, from outspoken nationalists to Catholic theologians, also participated. The result was a rich but also thoroughly inconclusive discussion, from which no consensus on roads beyond modernity could emerge.
\end{abstract}

Keywords: modernity; Westernization; nationalism; war; Kyoto School; Japanese Romanticism

DOI: $10.14712 / 23363525.2021 .19$

\section{Introduction}

Early to mid-nineteenth century was a period when a significant number of intellectuals were proclaiming the end of modernity. In Europe there were those like Oswald Spengler who wrote of the "decline of the West" and René Guénon who attacked Western modernity on behalf of Oriental tradition [Spengler 1961; Guénon 1996]. This was also related to the apparent decentering of the Eurocentric worldview. In Japan the discourse on modernity's end was tied to notions of the "fall of the West", but also to the "rise of the East", an overturning of the old order and its replacement by a new order from the East. On the international stage, what the Japanese called “the Greater East Asia War" (大東 覀戦争) was being waged in the 1940s, allegedly for self-defense and self-preservation of Asia against Western imperialism and to establish a new, pluralistic world order of Asian nations. ${ }^{1}$ Japan by then had successfully pursued its own modernization since the

* Dr. John W. M. Krummel, Associate Professor in Religious Studies at Hobart and William Smith Colleges. E-mail: krummel@hws.edu 
Meiji Restoration (1868) to raise itself to the level of the industrialized West. But modernization for Japan was also not without its problems, such as the waning of tradition, the widening of the economic gap between rich and poor, psychological as well as social turmoil and increasing sense of meaninglessness or ennui. Modernity was thus being challenged on two fronts: an "external war" against the modern Western (Anglo-American) nations and an "internal war" against the pro-Westernizing movement of "civilization and enlightenment” (支明開化) that imported many innovations from the West [Horio 1994: 293]. To the extent that "modernity" overlapped with "Western civilization", the discourse on modernity's end in Japan was tied to a self-identified "anti-European" basis and to the war being fought [Hiromatsu 1989: 157; Fujita 2018: 345-346]. On the basis of that background, “overcoming modernity” (近代の超克) became a popular slogan during the decades leading up to and through World War II, as a challenge to the culture and value system of modernity as such.

Yet, at the same time, overcoming modernity could not be without its contradictions in Japan. If modernity was simply Western and modernization was Westernization, the overcoming of modernity for Japan would just mean the overcoming of Western influence internally or Western imperialism externally. But Japan had already been modernized in its own forms, making the issue quite complex. ${ }^{2}$ A significant motivation for Japan's modernization was the feeling of vulnerability in the face of Western colonial expansion. The U.S. was pushing in from the East through the Pacific, European powers were coming from the West through India and Indo-China, and the Russians were claiming the islands north of Japan [Parkes 1997: 306]. The military strength that allowed Japan to resist Western imperialism was a product of its own drive to modernize. And there was a growing sense of pride in having entered world politics with the ability to defend itself and the region. The sophisticated Japanese critics of modernity thus could not afford to be exclusively nostalgic nor one-sidedly anti-modern. Ironically in its path to modernize and resist colonialism, Japan had to adopt the same colonialist policies of the West, beginning with the acquisition of Taiwan in the Sino-Japanese War (1894-1895), to the acquisitions of the southern half of the Sakhalin Island and control and eventual annexation of Korea from the Russo-Japanese War (1904-1905), increasing influence over China, the establishment of the puppet state of Manchukuo in 1932, and its attempt to gain control throughout China with the China Incident of 1937.3 After the war, Takeuchi Yoshimi (竹内好) (1910-1977) expressed this contradiction in his essay “Overcoming Modernity” (「近代の超克」) through a series of oppositional relations, e.g., restoration and renovation, royalty and exclusion, national isolationism and opening the country, ultranationalism and "civilization and enlightenment", East and West, and so on [Kawakami - Takeuchi 1979: 338; Takeuchi 2005a: 146]. In Takeuchi's view, this logic that the non-West (Asia) must become Western to resist the West, or become modern to resist modernity, is inseparable from those aporias of modern Japanese history.

1 This was the paradox of the war that Takeuchi states was at once a war of colonial invasion (植民侵略戦争) and war against imperialism (対帝国主義の戦争) [see Kawakami - Takeuchi 1979: 306].

2 Japanese modernity, for example, at the time was comprised of what Jason Josephson has called the "Shinto secular", Shinto as embedded in the structure of the modern nation-state [Josephson 2012: 230].

3 The China Incident is the July 1937 battle between China's National Revolutionary Army and Japan's Imperial Army that started the second Sino-Japanese War. 
We may be able to resolve that contradiction, at least to some extent, in light of Shmuel Eisenstadt's recent thesis on multiple modernities, by viewing Japan's quest to "overcome modernity" as a quest for a form of "alternative modernity". Eisenstadt argues that many of the nationalist and traditionalist movements that emerged in non-Western societies from the mid-nineteenth century up to the post-war decades "articulated strong anti-Western or even antimodern themes, yet all were distinctively modern" [Eisenstadt 2000: 2]. While the European pattern of modernity had spread throughout the world via economic, technological, and military expansion to non-Western societies, the appropriation of its elements allowed many to actively participate in developing new and various modes of modernity through selection, reinterpretation, reformulation, and innovation. The unique circumstances in Japan contributed to a Japanese form of modernity [Eisenstadt 2000: 14-16]. One might therefore argue that the "overcoming modernity" discourse in Japan manifests that distinct program of modernity and expresses its attempt to distinguish itself from the West. ${ }^{4}$ Eisenstadt however also recognizes the contradiction Takeuchi pointed to, and describes it as a tension between the self-recognition of critics of modernity as part of the modern world and their "ambivalent attitudes toward modernity in general and toward the West in particular" [Eisenstadt 2000:15]. Faced with that tension, intellectuals nevertheless were tasked to somehow interpret and give sense to what was happening. In that atmosphere of confusion, the phrase "overcoming modernity" evidently struck a chord to became deeply tied to the Greater East Asia War, evoking a common but ambiguous sentiment within intellectual circles [Fujita 2018: 344; Kosaka 2018: 245; Takeuchi 1979: 274].

My aim here is to examine the ideas and arguments of these wartime intellectuals in their discussions of modernity, with a focus on the in/famous symposium on "Overcoming Modernity” (「近代の超克」) held in 1942, whose proceedings were published in the journal Bungakkai (『文学会』; Literary World). ${ }^{5}$ I will argue that the attempt to "overcome" modernity expressed in the symposium, for many of the participants and in different degrees, can be understood as an attempt to assert and develop a modernity alternative to that of the West. I would like to follow this with an assessment of whether some of their approaches may be viable or not in our present but distinct context. ${ }^{6}$ I will begin by examing the thought of two thinkers who were important members of the intellectual currents represented in the symposium. Although they did not take part in the symposium their influence cannot be ignored.

4 Eisenstadt 2000: 14. For Eisenstadt [2000: 2] modernity involves processes of "continual constitution and reconstitution of a multiplicity of cultural programs".

5 Ever since Takeuchi's 1959 essay this symposium has been linked to, and often discussed together with, another series of three symposia held during 1941 42 and whose proceedings were published in the journal Chūōōron (『中央公論』; Central Review), and which had some overlapping participants. However, due to space, in this paper I will limit my discussion to the Bungakkai symposium and will discuss the Chūōkōron symposia in a separate essay.

6 In regard to the issue of complicity with the wartime regime, there has been a lot of mudslinging in the commentarial writings, especially in English, concerning these wartime discussions, with the use of ad hominem and strawman arguments on both sides, defenders and bashers. Here, in agreement with David Williams, I want to avoid what Roland Barthes called "the contagion of judgment" [Barthes 1975: 32; Williams 2014: 22], and resist the temptation to make moralizing judgments. 


\section{Immediate Predecessors in the Kyoto School and the Japan Romantic School}

Two intellectual currents represented in the "Overcoming Modernity" symposium were the Kyoto School (京都学派) of philosophy and the Japan Romantic School (日本 浪漫派) in literature and literary criticism. From those two schools two immediate predecessors of the symposium participants were Miki Kiyoshi (三木清) (1897-1945) and Yasuda Yojūrō (安田與重郎) (1910-1981). In these two we see two distinct approaches to modernity, despite their Marxist backgrounds.

Miki was a Kyoto School philosopher but also a Marxist, or at least an ex-Marxist, depending on one's perspective - his Marxism was never orthodox but he also never made any public conversion (転向), ${ }^{7}$ as did many other leftists, away from the Marxism of his earlier years. He had a close relationship to the symposium as an influential member of the Bungakkai journal coterie [Hiromatsu 1989: 147]. But although he was invited to participate, he was unable at the time, having been drafted by the Army. He was under scrutiny for his leftist activism and thus sent to Manila on a work assignment with the Army. Before that he was involved in Konoe Fumimaro's (近衛文麿) (1891-1945) Shōwa Research Association (昭和研究会), a prewar think tank established in 1930 for discussing political reform, and intended to inform Konoe's premiership; and then in the Imperial Rule Assistance Association (大政翼賛会), created by Konoe as Prime Minister in 1940 to promote the goals of his movement for a "new order". ${ }^{8}$ While contributing to Konoe's think-tanks, Miki had laid down the principles of what he called "cooperativism" (kyōdōshugi (協同主義) that was to avoid the faults of both mechanistic egalitarianism and despotic authoritarianism - the weaknesses of Anglo-Franco-American liberal individualism, Soviet Communist universalism, and the totalitarian ethno-nationalism of Germany - by grounding itself upon the organic spontaneity of the masses [Hiromatsu 1989: 146-147]. He argued for the necessity of such a philosophy to ensure that "if Japan's conduct in China is to be different from previous Euro-American imperialist invasions by the European and American capitalist nations, then its characteristic behavior must have a characteristic theory corresponding to it" [Miki 1967: 293; see also 242]. His "philosophy of world history" was also meant to correct the Eurocentric view of world history because "[t]he world, in its ideal state, should not be unicentral but multicentral" [Miki 1986: 12-13]. On this basis he advocated a "new intellectual principle" that can "overcome from a higher standpoint modernism, the signs of collapse of which are already manifest". According to Miki, "modernization of Japan has been largely a process of Westernization"; but what is to replace that Western modernity cannot simply be something intrinsically Japanese with no universality [Miki 1986: 6-7]. Just as Greek culture, in addition to its Hellenistic elements, had "certain universal elements" to profoundly influence world cultures, the point is to create a Japanese culture "possessing an equivalent generality in the oriental world" [Miki 1986: 9]. But this formation of a modern East Asian culture cannot exclude

\footnotetext{
7 This was a common phenomenon of "ideological reversal" or "conversion" during this period that the majority of Communist Party members and their sympathizers and other leftists participated in to usually embrace more "nationalist" ideals. On this see [De Bary - Gluck - Tiedermann 2005: 940].

8 Konoe liked to fill his think-tanks with intellectuals from both the Right and the Left, including ex-political prisoners in an attempt, as if, to accommodate the entire political spectrum for his "revolution" or "reform" of the government.
} 
or dissociate itself from Western modernity as Easterners must rely upon modern scientific methods [Miki 1986: 11]. Here Miki appears to be advocating a new form of modernity alternative to that of the West.

Yasuda, on the other hand, viewed modernity in Japan, identified with the movement of "civilization and enlightenment", as having no chance of rehabilitation. Its only path is decay and hence to be completely rejected [Kawakami - Takeuchi 1979: 334]. His ideal was instead the “passion for ruin” (脱落への情熱) which would break down the present “irony of Japan” (日本のイロニー). However, in his Japanese Bridge (『日 本の橋』) of 1936, he also called for a recovery of the “homeland” (故郷) through the “Japanese classics" (日本の古典) with its aesthetic sensibility, "antiquity when gods and men were all together” (神人同床の古代) [Harootunian - Najita 1993: 756; Hiromatsu 1989: 194-195; Yasuda 1985-1989a]. But he never adequately defined that primal antiquity aside from a vaguely romantic agrarianism. ${ }^{9}$ Yasuda explains how, as one of the last remaining Marxists, he was shaken by the Manchurian Incident ${ }^{10}$ and struck by its new worldview uncontaminated by the filth of politics. “Manchukuo" (満洲国) - the Japanese renaming of Manchuria - with its pan-Asianist ideal, came to represent for him a bold and daring ideal of civilization and revolution, in which he perceived the symbolic overcoming of Western modernity. And this signified for him the germination of the Japan Romantic School [Hiromatsu 1989: 191; Yasuda 1985-1989b]. He states that he retained his Marxism as an earthly expression of a worldview but that it ceased its relationship to the Soviet Union or even Marx and altered its meaning to simply become the struggle for justice. But he also viewed Marxism in a distinct sense to be the last stage in the "civilization and enlightenment" movement and viewed the Romantic School's special mission to be the toppling of this final phase and the starting of a new one, to build "a bridge in the night reaching toward a new dawn” (次の曙への夜の橋), an alternative to the modernity brought from the West [Harootunian - Najita 1993: 758; Hiromatsu 1989: 195; Matsumoto 1979: iv; Yasuda 1985-1989a].

\section{The Symposium on "Overcoming Modernity"}

The symposium on "Overcoming Modernity" was held on July 23rd and 24th, 1942, in Meguro, Tokyo, soon after the start of the Pacific War, among a large group of intellectuals, representing different academic disciplines and intellectual currents, at the invitation of the Bungakkai periodical, a popular but high-brow magazine of general interest. The event was planned and organized by Kamei, Kawakami, and Kobayashi (see below), literary critics involved in the journal. Takeuchi states that it was the most active forum for "centrist intellectuals" after the virtual annihilation of Marxism [Kawakami - Takeuchi 1979: 337]. Most of the essays were submitted prior to their roundtable discussions but a couple (by Miyoshi and Nakamura) were written as impression pieces (感想文) after the event [Kawakami - Takeuchi 1979: 285-286]. The proceedings, including essay contributions, were first published in the September and October 1942 issues of the journal and

9 That was Hiromatsu's critique of Yasuda. See Hiromatsu 1989: 194-195.

10 Also known as the Mukden Incident. This involved the 1931 explosion of dynamite close to a Japanese owned railway line in Mukden, a city in Manchuria, for which the Japanese Army accused Chinese dissidents and responded with a full invasion leading to the occupation of Manchuria. 
then published as a book by Sogensha in 1943. ${ }^{11}$ Among the participants involved in the symposium were members of roughly three intellectual currents: writers and critics, some of whom were editors of the Bungakkai journal, the Kyoto School philosophers, and writers and critics belonging to the Japan Romantic School, with overlaps among them.

Bungakkai was the gathering place of the New Arts School, a modernist literary movement, representing a "cultural liberalism", that aimed to assert independence of the arts from the Marxist Proletarian movement in the heyday of Marxism before its demise. But its ideas were miscellaneous and members too diverse to categorize though all were trained in Western literature. Its membership overlapped with the other two groups involved in the symposium as well as including ex-Marxists [Hiromatsu 1989: 180; Minamoto 1994: 205]. Author and literary critic Kobayashi Hideo (小林秀雄 (1902-1983) was the cofounder. Other members involved were literary and music critic and editor of the journal, Kawakami Tetsutarō (河上徹太郎) (1902-1980); poet and translator Miyoshi Tatsuji (三好達治) (1900-1964); literary critic, playwright, and novelist, Nakamura Mitsuo (中村光夫) (1911-1988); novelist, cultural critic, and ex-Marxist Hayashi Fusao (林 房雄) (1903-1975); and literary critic and ex-Marxist Kamei Katsuichirō (亀井勝一郎) (1907-1966). Of these the last two were also part of the Japan Romantic School.

The Japan Romantic School was a movement associated with the literary journal Nihon romanha (『日本浪漫派』), first published in 1935 and founded by the above-mentioned Yasuda. Both Hayashi and Kamei, who were part of the Bungakkai coterie were also members of this school and participated in the symposium. ${ }^{12}$ Yasuda was invited but did not participate due to a "sudden inconvenience". ${ }^{13}$ The constitutive elements of the school have been characterized as Marxism, National Learning (国学), and German Romanticism. Like the Marxists they were responding to post-World War I alienation and atomization. But for them revolution was to occur as an overcoming of Western modernity, including the complete negation of the "civilization and enlightenment" movement with which they identified Japanese modernity [Hashikawa 1965: 32; Hashikawa 2000: 25-26; Hiromatsu 1989: 193; Kawakami - Takeuchi 1979: 273]. The group rallied around Yasuda's manifesto to mark their collective break from Marxism and literary modernism. They felt the rational requirements of Westernized society and demands of mass markets had eroded the aesthetic sensibility of native Japanese culture, and so longed for a return to that ancient nativity with its sense of "wholeness" even while acknowledging this to be but an unreachable dream [Harootunian - Najita 1993: 756].

Of the three currents many would agree that the Kyoto School was the most intellectually coherent. In the broadest sense, the "school" refers to philosophers who were

11 They were published in the journal issue with the title "Conference Symposium on Cultural Synthesis: Overcoming Modernity” (「文化綜合会議シンポジウムー近代の超克」) but when published as a book by the publisher Sōgensha (Tokyo) in July the following year (1943), the book title became Conference of Intellectual Collaboration: Overcoming Modernity (『知的協力会議 近代の超克』) [Hiromatsu 1989: 255 n. 1; Calichman 2008: $x$ ].

12 Other members included writers like Jinbo Kōtarō (神保光太郎) (1905-1990), Nakajima Eijirō (中島英次 郎) (1910-1945), and Nakatani Takao (中谷孝雄) (1901-1995) and in the post-war years, novelists like Dazai Osamu (太宰治) (1909-1948) and Mishima Yukio (三島由紀夫) (1925-1970) were also associated with the movement.

13 Takeuchi infers from Yasuda's thinking of the time that he may have found such events meaningless [Kawakami - Takeuchi 1979: 287]. 
directly influenced by Nishida Kitarō (西田幾多郎) (1870-1945), whether as students or colleagues, during and after his tenure at the Philosophy Department of Kyoto Imperial University from 1910 to 1928 . Along with Nishida, his junior colleague Tanabe Hajime (田 辺元) (1885-1962), who shared many students with Nishida, is considered a co-founder. Besides the above-mentioned Miki, other Kyoto School philosophers had begun turning their attention towards political philosophy during the late 1930s and early 1940s. The ones involved in the “Overcoming Modernity" symposium were Nishitani Keiji (西谷啓 治) (1900-1990), Shimomura Toratarō (下村寅太郎) (1902-1995), and Suzuki Shigetaka (鈴木成高) (1907-1988). It was unusual that Miki, who was also part of the Bungakkai group, did not participate as he had often participated in other such symposiums, but this was probably due to his being drafted to work overseas for the Army press corps [Kawakami - Takeuchi 1979: 286-287].

In addition there were a handful of intellectuals not affiliated with any particular current: composer and music theorist Moroi Saburō (諸井三郎 (1903-1977); journalist and film critic Tsumura Hideo (津村秀夫) (1907-1985); Catholic theologian and philosopher of religion Yoshimitsu Yoshihiko (吉満義彦) (1904-1945); and nuclear physicist Kikuchi Seishi (菊池正士) (1902-1974).

The participants met to discuss the meaning, origins, and impact of modernity at a time when with the start of war, people were chanting slogans without intellectual reflection. Kawakami explained that the point was to discuss the current world situation and Japan's position within it, and to make sense of the war [Kawakami - Takeuchi 1979: 267]. After long years of international and domestic pressure and constant tension, especially since the Manchurian Incident of 1931, intellectuals saw the start of war as something that could lead toward resolution domestically and abroad, with a new structure replacing the old Western model of modernity. The symposium served to "... let some fresh air into the stifling intellectual atmosphere" [Horio 1994: 290] of the time by providing a venue for intellectuals to voice their thoughts to give some meaningful direction to the situation. What is shocking is that the discussions were even permitted during this period, and Karatani Kōjin thinks it may have been the only journal that sought to preserve "freedom of speech" as Marxism was completely suppressed by that time. But Karatani reminds us that its "liberalism" could only be literary and its "freedom" only aesthetic. ${ }^{14}$ Through the understanding of modernity as something received from the West and its association with Western colonial imperialism, the overcoming of modernity in some sense signified for many the overthrow of Western and modern ideas and influences along with the military defeat of Western hegemony in favor of a Japanese hegemony in East Asia and the Pacific. But of course, the real situation was more complex and the discussions reflected, in different degrees, awareness of that complexity. The symposium as a whole, however, failed to provide air-tight arguments or concrete suggestions or any unified front. Nonetheless the discussants took the issue seriously as their own, and its publication succeeded in rousing a generation of intellectuals right after the outbreak of the US-Japan war.

Between the different intellectuals participating, a variety of views were expressed, both in their submitted essays and in their discussions, in regard to "modernity", what it is and

14 Karatani 2005: 109. Nonetheless, Karatani states that in its "literary liberalism", the journal differed from the "trash pieces written by ideologues at the time" [Karatani 2005: 114]. 
what its "overcoming" entails. Most generally agreed that modernization in Japan since the Meiji period had led to a number of vices and misfortunes. Many spoke of the development of modernity in the West and its incorporation in Japan during the Meiji period with its "civilization and enlightenment" movement, its advantages and disadvantages. Hiromatsu Wataru discerns among them three axes that are not necessarily mutually exclusive: 1) the view that defines modernity as a "period of anthropocentrism" in contrast to medieval theocentrism; 2) the view that grasps modernity in terms of its economic, social, and political organization of capitalism; and 3) the view that conceives modernity as a "cultural typological" regulation in Western civilization's posture of world domination [Hiromatsu 1989: 179-180]. Fujita Masakatsu finds two opposing general views: 1) the view that the evils of modernization and "modernity" essentially do not belong to Japan but are alien, and that their overcoming entails turning back to, restoring, the "purely" Japanese aspects of the past; and 2) the view that "modernity" is not something other but rather an issue of one's self, the very place where one stands [Fujita 2018: 348]. Minamoto Ryōen sees the participants' views to modernity split between those who argued modernity is something to be overcome and those who argued for a recognition of its value [Minamoto 1994: 207-208]. I think one can notice all of these positions, but the general underlying assumption was that modernity was originally a European phenomenon that influenced Japan's modernization. As the more pernicious consequences of modernity, many agreed upon the extreme degree of specialization in various disciplines, the dehumanization, mechanization, and quantification resulting from technological and scientific "progress", leading to a sense of lack of wholeness and alienation. They also expressed anxiety over the loss of an appropriate Japanese character and identity. Overcoming modernity as such would be the overcoming of Japan's self-alienation and a path of self-restoration [Calichman 2008: 11-12]. In the face of the crisis on many different fronts, especially the war, the organizers felt the need to consolidate the efforts of intellectuals to contribute to solidarity with a "more rational and practical solution to the problem of Japanese modernization" [Calichman 2008: xi]. Yet some discussants recognized a certain ambiguity in the terms, "modernity" and its "overcoming" and questioned the coherence of this task. In the following I will summarize the views of each participant.

\section{The Bungakkai Coterie}

Among the intellectual currents represented, the Bungakkai coterie was the least intellectually coherent and most diverse in their stance. Among them Kawakami distinguished "our Japanese blood that had hitherto been acting as the real driving force of our intellectual activity" from "the Western intellectuality that had been awkwardly systematizing it" [Kawakami - Takeuchi 1979: 166]. "Modernity" would belong to the latter as something like a jacket borrowed from another to cover oneself, but leading to awkwardness, discomfort, and tension [Fujita 2018: 349].

Among the Bungakkai group, Kobayashi was the one most deeply preoccupied with the difficulty of maintaining a Japanese identity and came close to the position of the Japan Romantic School [Kawakami - Takeuchi 1979: 289]. In the symposium he exclaims that, while Western modernity is a tragedy, Japan's modernity, with its rush to imitate, has been a comedy. For the truly creative standpoint that addresses the question of enduring 
forms of beauty has no need for the new; beauty does not "evolve" to progressively become modern. Aesthetic creations are "unhistorical". Humans are always struggling with the same issues and that sameness is eternal. The modern perspective of history prevents one from encountering, and makes one forget, those unchanging structures [Kawakami - Takeuchi 1979: 219-220]. He thus equates overcoming modernity with the rejection of the modern view to history as continuous progress. Overcoming the linear concept of time is thus the key.

In contrast to his Bungakkai colleagues, Nakamura noticed an ambiguity (曖昧), in both concept and practice, of the task of "overcoming modernity". It would be simple if one could just take "modern" to be synonymous with "Western". But to borrow a concept from the West in order to reject the West, he argues, would be a thoughtless contradiction. Contemporary Western intellectuals have already been expressing this project of "overcoming modernity" [Kawakami - Takeuchi 1979: 150, 155]. By the time of the Renaissance and with the ending of feudal society Europeans had begun discovering unknown worlds. They also found that unconditional belief in God was unnecessary. Nakamura argues therefore that the basis of European modernity lies in this spiritual state of having always to live among the unknown and search out the new [Kawakami - Takeuchi 1979: 203]. Europeans have had to live through this experience with its disillusionments. Nakamura thus asks whether the words "overcoming modernity" resonate for Japanese intellectuals with the same sort of emotive intensity and clarity of content as it must have for Europeans. Have the Japanese truly self-reflectively lived through modernity in the same way when modernity has been "a hasty foreign transplant", a superficial import? [Kawakami - Takeuchi 1979: 150-152]. As if to ridicule the entire project of the symposium Nakamura confesses that for him, the words do not sound with the same intensity or clarity. ${ }^{15}$

Modernity in Europe is domestic but in Japan it is an import. To speak of "modernity" while ignoring the superficiality of Japanese modernity, Nakamura proclaims, is no more than "a meaningless idealistic game" [Kawakami - Takeuchi 1979: 152]. And yet the Japanese have already been irrevocably Westernized through the violent and frenzied change following the Meiji Restoration, to the point of no return. This rapid absorption of foreign civilization was necessary for the country's survival, a matter of life and death. But the unquestionable superiority of the West's material civilization had created a sense of credulity in proportion to the shallowness of people's understanding of the West. The import of Western culture was focused on its scientific civilization but science is the result of rigorous training. He argues that it was not really science as tradition or practice but instead only a pile of ready-made scientific knowledge (科学的知識の集積) and technology that was imported and incorporated without the necessary time to digest that knowledge [Kawakami - Takeuchi 1979: 158-159]. The possession of that knowledge is not the same as understanding or grasping its meaning. If the Japanese people hastily cram that ready-made knowledge into their minds, they will lose the ability to think for themselves. Nakamura includes among such thoughtless and superficial trend-chasers even those who advocate reviving the classics for cultural self-awakening [Kawakami - Takeuchi 1979: 163]. Modernization in many fronts has thus contributed to a "deformity in spirit". So the first step to

15 Takeuchi notes that Nakamura's essay, written after the roundtable sessions, during which he rarely expressed his thought, was clearly written as a critique of the symposium as a whole [Kawakami - Takeuchi 1979: 292]. 
its overcoming would be in clearly recognizing this spiritual crisis as an internal enemy (身 内の敵), and then to truly comprehend the West. Despite raising these concrete issues, his questions were not taken up in the roundtable discussion. His views stand out, however, as among the more sophisticated positions expressed among the Bungakkai group and in the symposium as a whole.

\section{The Japan Romantic School}

The representatives of the Japan Romantic School were Kamei and Hayashi, but both, as mentioned, were also part of the Bungakkai group. Hayashi described Japan's adoption of European culture as its submission to the West and faulted the "civilization and enlightenment" movement as responsible for the forgetting of the value of Japanese tradition and lineage. While Japan managed to restrain and resist the West, it could do so only by incorporating Western utilities and practical culture. In the attempt to ward off the Western imperialist threat and remodel itself into a modern nation-state, Japan ironically had to become foreign to itself, losing sight of its own true nature (本然の姿) [Kawakami - Takeuchi 1979: 110]. Among these Western imports Hayashi includes the spread of capitalism, the introduction of machine civilization, and the importation of democracy, liberalism, individualism, rationalism, utilitarianism, bureaucracy, specialization, mass production, consumerism, and so on, all devoid of any value or substance [Kawakami Takeuchi 1979: 239-240]. Instead Japanese society has been corrupted by the pervasive rule of money and domination of vulgarity. But without historical recollection and realization of lineage, there can be no "living Japanese" who can create history. To purify Japanese identity from contamination, he thus calls on Japanese literature to "return to your true nature!” that can be found “in the heart of imperial loyalty” (勤皇の心), lying within and beneath the sedimented layers of Westernization and to cultivate it [Kawakami-Takeuchi 1979: 111].

Kamei, likewise in true Romanticist vein, traced the root of contemporary confusion back to the "civilization and enlightenment" movement of the Meiji era. If Hayashi looks to imperial loyalty, Kamei looks to the gods or kami (神) of Japan. Confusion, under the influence of foreign ideas and the spread of science has led to the loss of faith and sight of the gods. From the day the Japanese took over "modernity" from the West, the greatest enemy has been a lifestyle that slowly and deeply violates the spirit with its poison, spawning illusion and chatter, an illness or virus that everyone now carries [Kawakami - Takeuchi 1979: 6, 201, 202]. The consequence has been a decline in sensitivity (感受性) and the subjugation of man through machinery (機械) [Kawakami - Takeuchi 1979: 9, 12]. The increase in specialization and compartmentalization in various fields of knowledge, along with the increasing spirit of utilitarianism, has been a major disruptive force, leading to the loss of spiritual unity among the fields or disciplines but also of the wholeness of human nature (全人性). To overcome this era of exile from the gods, he longs for faith in - and rebirth of - the gods, a reintegration with the spirit of the kami [Kawakami - Takeuchi 1979: 200]. Interestingly, he also objected, however, to interpreting the classics by means of ruling slogans and empty catch-phrases and their circulation that promotes the vulgarization of language. He thus critiqued the deterioration of spirit that had surfaced under the sham excuse of "war time" [Minamoto 1994: 213]. In conclusion, he calls for a "holy war" 
with two aspects. While the war outwardly aims to overthrow the Anglo-American forces, internally it aims to cure the psychological or spiritual malaise brought about by modern civilization [Kawakami - Takeuchi 1979: 15]. Members of the Japan Romantic School thus in general underscored the presence of that original Japanese identity - "the true nature" for Hayashi, faith in kami for Kamei - that distinguished Japan from the rest of the world. Such views of the Romanticists, however did not always mesh well with that of the Kyoto School thinkers.

\section{The Kyoto School}

The Kyoto School's approach to modernity was more systematic in comparison to the others. Suzuki, who specialized in European medieval history, makes the distinction between modernity as applied to Europe and to Japan. The situation in Japan is complicated because the issue of overcoming modernity overlaps with the issue of overcoming Europe's world domination - the reason behind the Greater East Asia War - when modernity has also already been deeply internalized to become part of the Japanese people [Calichman 2008: 146, 147; Kawakami - Takeuchi 1979: 176]. He points out that even in Europe it has been disputed whether the modernity to be overcome is the nineteenth century that produced democracy, liberalism, and capitalism, or goes all the way back to the Renaissance. He suggests, however, that the nineteenth century was a necessary consequence of the development of the modern spirit traceable to the Renaissance, while also suggesting that modernity truly emerges at the end of the eighteenth century, having gone through the necessary developments of the Renaissance, the Wars of Religion, the post-Enlightenment, the emergence of civil society and capitalism, the French Revolution, and the emergence of science [Kawakami - Takeuchi 1979: 180]. He adds to this that one way to overcome modernity may be to look back to the medieval period and reflect on our indebtedness to it [Kawakami - Takeuchi 1979: 186].

Through the "civilization and enlightenment" movement Meiji-era Japan had been transformed into a great modern power. But Suzuki, like Nakamura, points to the fragmentary and superficial nature of the Japanese understanding of Europe [Kawakami - Takeuchi 1979: 241]. He reminds the others, however, that modernity in Japan is no longer alien as it has been deeply internalized to become part of the Japanese. What had been adopted was nineteenth century modernity - democracy in the realm of politics, capitalism in the realm of economics, and liberalism in the realm of thought - elements of modern civilization that contemporary Europeans are in the process of reexamining. This in turn has awakened an intellectual crisis in Japan as well. But since Japan has already become a powerful modernized country, the contradiction is deep and the issue cannot be resolved by a simple denunciation of the foreign [Calichman 2008: 147]. For modernity's overcoming is many-sided even if it involves issues relating to the foundation of worldviews and the nature of civilization. Although Suzuki's formulation covers almost the entirety of the gamut of issues, the roundtable discussions ignored his suggestions. He ended up withdrawing his submitted essay later from the book version of the proceedings. ${ }^{16}$

16 His essay, “A Note on 'Overcoming Modernity” (「「近代の超克」覚書) was published in the October 1942 issue of Bungakkai, 41-43, but he withdrew it from being published in the book version that appeared in 1943. 
Fellow traveler of the Kyoto School, Shimomura states in the symposium that modernity originates in Europe and its overcoming, as a Japanese problem, means a confrontation with European modernity. This means that the issue of Japanese modernity is not necessarily identical with the issue for Europeans [Kawakami - Takeuchi 1979: 112]. Like Nakamura's point about science, Shimomura states that the Japanese had received only the outcome of modernization, its external institutions and technology, while discarding its "internal spirit or ethos" [Kosaka 2018: 236] and without historically experiencing the process of modernization. But insofar as Japan had been modernized and hence Westernized, "Europe is no longer a mere other [他者]" and "modernity is us, and the overcoming of modernity is the overcoming of ourselves ..." [Kawakami - Takeuchi 1979: 113]. Its overcoming then must be accompanied by self-critique.

As if directing his remarks at Kawakami or the Romantics like Hayashi and Kamei, Shimomura also mentions how it would be dishonest to simplistically take modernity as an "age of misfortune" without recognizing its positive aspects [Kawakami - Takeuchi 1979: 115]. While things become specialized (専門化) or differentiated (分化) in modernity, this in itself is not equivalent to decadence for specialization has a certain purpose. Even the supposed opposition between religion and science is not a real conflict but an opposition between certain religious dogmas and certain scientific theories and is eliminated in modernity once each is purified of the other - specialized - as science loses its status as naïve metaphysics and religion loses its status as naïve science [Kawakami - Takeuchi 1979: 237]. One main incentive behind the European discourse of overcoming modernity lies in the degeneration of culture into a mechanized civilization in which people are enslaved to machinery. But Shimomura reminds us that the invention of machinery was to free us from slavery and wonders if the assumption of the purity of medieval spirituality may be an idealization [Kawakami - Takeuchi 1979: 113-114]. Against the medievalist Yoshimitsu, who looked to a return to the medieval, he points out that it is meaningless as well as impossible to return to the past to seek some lost unity belonging to the medieval era. To simply point to man's enslavement to machines would be cliché when machines were originally meant to liberate. He explains the origin of machinery to lie in the technical nature of science, a characteristic of modern knowledge that attempts to overcome, or work with, nature and its laws. This involves idealism as the spirit that recognizes all being to be mediated by the knowing subject. Even empiricism and positivism as well as the Protestant Reformation were informed by this spirit of idealism [Kawakami - Takeuchi 1979: 188]. Shimomura therefore traces modern science not to materialism but to idealism (観念論). He argues that this modern approach to cognition is what led to the formation of machines and the resulting reorganization or reconstitution of nature, establishing the objective (客観的) independence of the human spirit [Kawakami - Takeuchi 1979: 114-115; Minamoto 1994: 211]. If humanity today is indeed enslaved by machinery, it is not the responsibility of machines but rather of the institutions operating them and ultimately the human spirit who created and runs machinery. It is not really machine civilization but rather the machine-making spirit itself that needs to be problematized [Kawakami - Takeuchi 1979: 271].

The speculation by several commentators has been that this was due to his disappointment with how the discussion progressed. It was only published much later in 1980 [Kawakami - Takeuchi 1979: 287; Hiromatsu 1989: 87; Minamoto 1994: 209]. 
The tragedy of modernity, for Shimomura, lies rather in the inability of the old model of the soul to keep up with the new modern body whose organs are no longer the fleshly body but machinery [Kawakami - Takeuchi 1979: 116, 262]. It is an issue of imbalance. The point is not to reject the civilization of machinery but for culture to positively catch up with, and rule, that civilization. The particular Japanese task vis-à-vis modernity then is not about replacing it with some "purely" Japanese element of pre-modernity but "to reflect and critique what we had received and how and to what extent we had received it. This is the sole content of the issue of overcoming modernity for us" [Kawakami - Takeuchi 1979: 112]. What is needed is a new metaphysics, a new "theory of spiritual cultivation", for the modern bodymind. Shimomura's explication and characterization of modern science, however, was generally ignored, and the issues he set before the symposium did not get far in the roundtable discussions [Hiromatsu 1989: 28; Minamoto 1994: 212, 227].

Nishitani, the most well-known of the three Kyoto School participants today, had already previously written works on related themes, and contributes his insights from them to the symposium. He expresses his view of modernity as something situated politically, economically, and culturally at the end of post-Renaissance or "early modern" (近 世) Europe when its "world" began to spread to the rest of the globe. Modernity in Japan was introduced after the Meiji Restoration, but in a fragmentary manner when Western culture had already splintered into various specialized fields, having lost its unifying center and unified worldview [Kawakami - Takeuchi 1979: 19]. The culture of the early modern period made its decisive break from the medieval period through the three movements that established the religious Reformation, the Renaissance, and natural science as sources for proceeding intellectual currents. But these streams that have dominated the spiritual culture of the modern West are fundamentally discordant, each harboring a radically distinct worldview [Kawakami - Takeuchi 1979: 19-20]. The Reformation represents the standpoint centered on God, natural science represents the standpoint centered on the natural world, and the Renaissance represents the standpoint centered on humanity or the soul. The three pillars of human existence have splintered and fallen into unbridgeable fission. By contrast, in medieval Europe they were harmoniously united under the Christian creed. But in modernity each stands alone, claiming to sustain the whole [Kawakami Takeuchi 1979: 20-21]. Japan, to survive, was forced to incorporate Western culture with its practical organization of fields like science, technology, economics, government, and so on. But Western culture's own discordant division has infiltrated post-restoration Japan, threatening to split the very foundation Japan's unified worldview would be built upon, leading to its current confusion [Kawakami - Takeuchi 1979: 21].

Nishitani's response to that modern confusion is to probe into the depths of subjectivity, to its bottomless abyss beyond the limits of the modern subject, on the basis of which an ethics for the world can be erected. Modern epistemology postulates the opposition between subject (主観) and object (対象). Modern man seeks to establish his own subjectivity by positing this opposition, transforming others into objects while constituting itself in relation to that object. Nishitani's response is to invoke the Nishidian concept of absolute nothingness (絶対無) as the foundation giving rise to both terms of the oppositional logic. Nishitani develops this concept of nothingness in his own terms as the "standpoint of subjective nothingness" (主体的無の立場) [Kawakami - Takeuchi 1979: 29]. As true subjectivity (真の主観性), not a being, it is not some thing that can be grasped objectively 
but rather an act of free spontaneity. A selfless ethics is to be constructed on the basis of a religiosity that probes into the depths of subjectivity and down to this "standpoint of subjective nothingness", where we act in pure spontaneity but without ego. This permits culture, history, and even science the freedom to pursue their own standpoints [Kawakami - Takeuchi 1979: 23-27].

Nishitani claims this standpoint of subjective nothingness to be the original spiritual dispensation of the Japanese traditions which can provide its own unique authentic redefinition of modernity, a reconstruction of a united foundation for the formation of a new worldview and self-realization of the new man. He claims Japan to be the only country where this Eastern religiosity has been closely bound to national ethics to become the nation's cornerstone [Kawakami - Takeuchi 1979: 29]. As the only non-European country to have developed the strength of a European nation, Japan thus bears the task to construct a new world order in Greater East Asia. But this must mean the founding of a just order to replace the old order of European colonialism [Kawakami - Takeuchi 1979: 32]. The overcoming of modernity is to be realized through the immediate interpenetration between the religious nature of the world (世界宗教性) and the ethical nature of the nation-state (国家 倫理性), channeling its moral energy (道徳的エネルギー) based on subjective nothingness to the rest of the world. ${ }^{17}$ The nation must step beyond its self-centered standpoint by grounding itself on that selfless standpoint of subjective nothingness, opening up a "horizon of the communality of nations" based on the "nonduality of self and others" (自他不 二) and “self-benefit in benefitting others" (自利利他) [Kawakami - Takeuchi 1979: 36]. The task of overcoming the spirit of modernity consists in securing the ethical nature of this moral energy (道徳的エネルギーの倫理性) running through individual, state, and world [Kawakami - Takeuchi 1979: 34; Minamoto 1994: 220]. Each nation can then take its place within the community of a Greater East Asia. Japan's leadership within that community is justified on the basis of its self-awareness that this spirit has originally been part of Japan's tradition [Kawakami - Takeuchi 1979: 34]. Japan can thus claim self-negating altruism in its guidance of East Asia.

In a certain sense Nishitani's claim to Japan, rather than any other nation, as the bearer of this ethical nature, seems to reify the nation's special status despite its grounding in the unreifiable and pre-substantial unground of nothingness, and if so, one might accuse him for logical inconsistency. Questions arise whether his statements pertain to Japan's a priori essence or to the consequence of historical development. But despite certain Orientalist or Japanocentric ideas, including the characterizations of nothingness as “Oriental” (東洋的) and manifesting especially in Japan, this concept of nothingness, fraught with ambiguity, also points to a deconstructive undertow through its attributed self-negation. Even while repeatedly locating it in the Eastern, in particular, Japanese tradition, Nishitani also describes it as the abyssal un/ground transcending all dichotomies. Followed consistently, this logic of nothingness and self-negation would destabilize and undermine all substantializations or hypostatizations, revealing binary oppositions - such as East and West, or Japan and its other - to be contingent. In presupposing Japan's role

17 Kawakami - Takeuchi 1979: 29. Nishitani took over this concept of moralische Energie from the German historian Leopold von Ranke and expanded it as "the driving force of national ethics ... [that] is directly the driving force of a world ethic ..." to prevent injustices [Kawakami - Takeuchi 1979: 33]. 
as representative of the East vis-à-vis the West, Nishitani assumes the very framework of East/West dichotomy, so much a part of the "overcoming modernity" discourse in its anti-Eurocentrism, but which, to a large extent, had itself been inherited from Western modern Orientalist discourse. But his notion of subjective nothingness would paradoxically unground and expose as contingent, along with other dichotomies, this oppositional logic of East vs. West. ${ }^{18}$ The irony is that in the very attempt to overcome modernity, Nishitani on some level repeated that dualism belonging to the modern framework that opposes the "modern" qua Western to a reified traditional East, represented by Japan. On another level, however, Nishitani argued for Japan's own form of modernity that may not easily fit into the dichotomization of East vs. West. For the concept of nothingness, while historically rooted in the Eastern traditions of Mahāyāna Buddhism, Daoism, and Zen, does not have to be denied universality for the sake of its historical origins, any more than the idea of a monotheistic God having roots in the Mediterranean and Middle Eastern context. ${ }^{19}$ The real question is whether such a concept indeed is viable or makes sense beyond its cultural origin.

One could argue that the nothingness invoked by Nishitani - in both its lineage and de-reifying content, both pre- and post-modern - provides a deconstructive route out of modern anthropocentrism and metaphysics. As the division of the globe into two hemispheres of East and West is today breaking down to unveil a greater chiasmic complexity along with the inherently porous nature of cultures, the concept of "nothingness", as an un/ ground (Abgrund) of the world, is especially apt for this deconstructive, including self-deconstructive - self-negating - significance that undermines essences, including its own self-reified essence, predicated upon ethno-nationalist assumptions. Taken as an abyssal space it provides a clearing for the plurality of cultural differences as well as for novelty and change. If modernity marks the peak in the development of Western ontology in its perspective of being qua substance in terms of nature (phusis) in the ancient world, God for the medievals, and finally the subject (cogito, I, Geist), from Descartes to Kant to Hegel, with its anthropocentric imposition upon, and objectification of, the rest of reality and the world, its overcoming suggested by the Kyoto School would be through its desubstantialization in the abyssal nothing(ness) as its un/ground but also as an openness for difference and plurality, alterity and alteration. Taken in that sense could it not be a clearing for multiple modernities as well?

\section{Other Participants}

Participants from other currents and disciplines expressed a variety of other views. The music composer and theorist Moroi expressed his view that Japan's modernity came about by imitating Western civilization as a jumble of both good and bad elements. European modernity with its anthropocentric view is now in decline so the Japanese people need

18 Calichman argues that this inconsistency conceals Nishitani's reactive wish for an exclusively Japanese identity, vis-à-vis the West, the desire to see the Orient, and especially Japan, as unique [Calichman 2008: 19-20].

19 Any concept that one looks to as grounding principle, for which one claims universal validity, for that matter originates in some specific cultural context. Nothingness, on the other hand, is not necessarily an idea exclusive to the East as similar insights have been intimated or expressed on the margins of the Western tradition as well, e.g., the nothingness beyond, before, and not delimited to God the person. 
to awaken to this fact and confront its disorder [Kawakami - Takeuchi 1979: 39, 50]. One sense of overcoming modernity for Japan would be through a national reflection and thoroughgoing critique of Japanese modern culture. It would involve grasping the essence of Western culture, critically and systematically, to distinguish between what ought to be adopted and what ought to be abandoned. The positive sense of its overcoming would also mean building up Japanese culture and recovering its spirit (精神) by returning the sensual (感覚) to its original place, restoring everything in accordance with the spiritual order (精神の秩序). But in relation to the Japanese classics, their pursuit must be done with an attitude that “restoration is renewal” (復古とは維新である) [Kawakami - Takeuchi 1979: 55, 56]. In music overcoming modernity transfers into creating new music that is essentially spiritual, rescuing music from the art of sensory stimulation and restoring it to the art of the spirit [Kawakami - Takeuchi 1979: 38, 206-207].

The Catholic theologian Yoshimitsu focused more on modernity as a Western problem, which he diagnoses metaphysically and theologically as a problem of fundamental spirituality and of atheism. Western modernity has led to the "violent whirlpools of modern society" from the Renaissance to the French Revolution to Communism [Kawakami Takeuchi 1979: 60-61]. But this is also a problem for Japan. He agreed with Nishitani in the roundtable that there existed a unity in the Middle Ages between religion, culture, and ethics, which then became disintegrated in modernity. The Renaissance involved the loss of true, living religious spirituality, an estrangement from medieval Christianity [Kawakami - Takeuchi 1979: 182-183]. And with modernity's anthropocentric rationalism and liberalism came the dissolution of the ideas of an external spiritual kingdom and inner religiosity. This "crisis of the West" has spread over the entire planet to become an issue for present-day Japan as well [Kawakami - Takeuchi 1979: 182]. In this worldwide crisis, modern man is a tragic figure who must rediscover God [Kawakami - Takeuchi 1979: 185]. Yoshimitsu orients this objection to modernity toward the Middle Ages as a time of faith that can cure modernity's faithlessness - a move toward what Nikolai Berdyayev (1874-1948) called the "new Middle Ages". As if to warn against current trends in Europe - especially Nazi Germany - he adds that this cannot be just a reactive negation of modernity nor a return to a pre-Christian Germanic ground of the people that would signify an apostatic idolatry of a new pagan myth [Kawakami - Takeuchi 1979: 76]. So the problem of "conquering modernity" is a question of how to revive this universal principle of unity, how Europe can once again rediscover God and how Japan, given the influence of modern European culture, can also rediscover God [Kawakami - Takeuchi 1979: 182]. Referring to Catholic poet and philosopher Charles Péguy's (1873-1914) call for a fundamental spiritual revolution against modernity, Yoshimitsu clarifies that modernity's overcoming will be a return to the religiosity of medieval Catholicism, represented by a theocentric humanism or what Jacques Maritain (1882-1973) called "integral humanism" (humanisme integral), oriented to a supernatural life of grace. He believes that with repentance of Western modernity, a liberation from the modern ego through the penitence of the soul, a new East Asian spiritual civilization will be built [Kawakami Takeuchi 1979: 79-80]. The others in the symposium, however, not sharing his Catholic faith, ignored his proposals.

In the 20th century the U.S. has increasingly come to replace Europe as leader of the West. Some of the discussants talked about how this has led to the increased importation 
of American culture with its "crass, hedonistic materialism" and the cult of "fast living" and "eroticism" depicted in American movies and spread through mass production strategies to undermine traditional culture and values [Harootunian - Najita 1993: 765-766]. Journalist and writer Tsumura focused his critique on the American culture that Japan had imported following the Taishō era (1912-1926) [Kawakami - Takeuchi 1979: 124, 125-126, 134-135]. In his attack Tsumura also targets democracy as a movement that levels things down to the average, and material and machine civilization that allows us to live as cheaply and as easily as possible while also contributing to the levelling down [Kawakami - Takeuchi 1979: 260]. In comparison to this contemporary spirit (現代精神), infected by Americanism, the modern spirit (近代精神), for him, has still much to offer. ${ }^{20}$ Tsumura found it thus imperative to manage machinery so as to prevent it from consuming human life, and to inherit the Japanese classical spirit and tradition together with the modern spirit of the West. In order to conquer Americanism, he thus pointed to the common cultural will in both Europe and Japan - he has in mind the Axis powers - to overcome the old world order [Kawakami - Takeuchi 1979: 122, 127, 129].

Kikuchi, the physicist, on the other hand expressed a similar ambivalence towards the project of overcoming modernity as Nakamura. His view was that there is neither modernity nor antiquity in science [Minamoto1994: 207]. If it is indeed the case that modern scientific thought has negated everything divine and spiritual, this would be a serious problem. But he finds that idea to be the reductive or simplistic perspective of materialism with its naïve realism. Kikuchi claims that this would not be a problem if we could understand that the world, grasped scientifically, is but one aspect of a larger world, which he suggests could be the nothingness discussed by Nishitani [Kawakami - Takeuchi 1979: 145, 149]. He thus side-stepped the entire issue of overcoming modernity as a problem.

\section{Conclusion}

As we can see, a wide variety of views, including both affirmations and rejections of the modern, were expressed in the symposium on "Overcoming Modernity". But it lacked any deep interaction among the participants and failed to result in a unified understanding of what "modernity" is. Nor did it unfold any coherent argument or concrete scheme that everyone can agree on for the direction of its "overcoming". Kawakami, as chair, confessed in regard to the unclarity of the title, that it was meant to serve more as a slogan he thought he could throw at the participants to spur them towards some common sentiment. But without any consensus on what the conference was even about, both before and after the event, no consistency in thought ever emerged from their presentations and discussions. Even as the participants failed to engage each other's arguments, there were tensions and differences discernible throughout the roundtable discussions [Fujita 2018: 346-347]. Despite some interesting suggestions and insights from a few individuals like Nakamura, Shimomura, and Suzuki, the conference failed to clarify the task, or meaning, of overcoming modernity.

20 Kawakami - Takeuchi [1979: 135]; Minamoto [1994: 210]. During the roundtable interchange Suzuki responded to Tsumura's simplification of American culture by pointing out the Puritan element in American culture which is quite different from what Tsumura had been talking about [Kawakami - Takeuchi 1979: 258]. 
There was the common wish, however, to reflect on the current situation at a time of anxiety [Minamoto 1994: 200]. Most, despite differences, sought the alternative ideal within something "Eastern" or "Japanese". Looking to an ideal in the past and conceiving the present as a "fall", some, in the form of a "Romanticist reaction", called for a renaissance or restoration - recovering one's "heart of imperial loyalty" for Hayashi, halting the vulgarization of language for Kamei, and so on [Calichman 2008: 7; Hiromatsu 1989: 99]. The "primal Japanese" ideal they looked to was not merely an idealistic being of the past but embodied in the present nation-state and society of modern Japan even if infected by the "poison" of "modernity". But the participants recognized, to varying degrees, that they cannot simply reject the whole of modernity. To that extent, Hiromatsu notices, they intended a reformation rather than mere regression [Hiromatsu 1989: 99-100]. And here one might argue that the overcoming of modernity for them would in fact be the construction of an alternative modernity proper to East Asia. The mere appeal to return to Japan's original identity to become more Japanese was not without certain risks - as Calichman notes - since Japan's own colonial expansion had opened, or broadened, Japanese identity, making it accessible, beyond native Japanese, to Taiwanese and Koreans as well - Taiwan having been annexed in 1895 and Korea annexed in 1910. Moreover the figures of Japanese identity as historical representatives or symbols of Japaneseness that some participants appealed to - the emperor, the Japanese language, the Japanese classics, and so on - as embodiments are governed by contingency and thus can sabotage the project from within. ${ }^{21}$ At the same time, the Japanese as the most modern of Asians and having fallen victim to the “infection” (感染) of modernity or Americanism, placed the attempt to restore that idealized origin in jeopardy. To the extent that it was no longer possible to speak of Western modernity as simply foreign or alien, the question of overcoming modernity demanded a kind of self-critique. Calichman lines up expressions of this sentiment nicely: Overcoming modernity is "an overcoming of ourselves" (Shimomura); it requires "recognizing such spiritual crisis as an internal enemy" (Nakamura); "the poisons ... circulate within our body" (Kamei); the Japanese intellectual himself is the site of the dualism between "Japanese blood" and "Europeanized intellect" (Kawakami); and "European civilization has today already become deeply internalized ... no longer merely ... alien ... but ... part of us ... the modernity ... to be overcome exists ... within us as well" (Suzuki) [Calichman 2008: 17, 145, 146; Kawakami - Takeuchi 1979: 113, 164, 166, $176,201,202]$. Calichman notices as operating here tacitly, or in "repressed form", a logic that can account for, but ungrounds - un/grounds - the oppositional framework of native vs. alien, East vs. West, opening one up to alterity, the tacit recognition of the porosity of their culture among the participants, its originary openness to alterity that would call into question claims to essential, hence "pure", determinateness [Calichman 2008: 20, 23]. For there can be no notion of a culture or identity in its purity when external elements are always mixed up in its originary constitution. Calichman convincingly argues that the source of this crisis of modernity as a crisis of identity might simply be historical and that the self - whether individual or collective - exists in principle in crisis in its exposure to alterity over which it has no control [Calichman 2008: 18]. If so, the attempt to overcome

${ }^{21}$ Calichman $[2008: 14,15,16]$. What comes to mind is the recent Emperor Akihito's voluntary abdication of the throne due to being "tired". 
the crisis of modernity may itself be a modern condition along with the crisis. But one could also argue, as I mentioned above, that this historicity and contingency is precisely implied by the notion of nothingness Nishitani invokes.

The symposium, once published, however, obtained a popular reputation, probably due more to its attractive title than to the coherence of its intellectual content, but also because of its timing and circumstances. Hiromatsu states that it had a massive impact on the intellectual youth of the time, speaking emotively rather than intellectually to their sense of despair [Hiromatsu 1989: 181-182]. For intellectuals, "overcoming modernity" represented a far loftier idea than military victory over Anglo-American powers or even world conquest, an idea expressing a grand task, vague enough and sufficiently undefined to work as a unifying incantation for young intellectuals, looking to make sense of the war. But Hiromatsu also suggests that the symposium may also have served as a kind of advertisement for the Kyoto School's "philosophy of world history" that would give some "theoretical" composition to the theoretical chaos of the Japan Romantic School and the Bungakkai coterie and which was discussed with much greater depth, and in detail, in the parallel symposium organized by Chūōkōron [Hiromatsu 1989: 201].

Among the two major leftist philosophers of contemporary Japan who have commented on this symposium, Hiromatsu underscored the overlap in intention the symposium's discourse shared with the Shōwa Restoration movement despite their distinct lineage. ${ }^{22}$ Karatani on the other hand views this symposium as exemplifying a "literary liberalism" that differed from the more bombastic "trash pieces" written by ideologues of the time [Karatani 2005: 114; see also Karatani 1989]. But it also cannot be denied, as both Karatani and Hiromatsu would agree, that the interpretation, expressed in the symposium, of the Pacific War as a revolt against Western modernity and its hegemony over Asia was a view not unattractive to the Marxists who by that time had been forced underground and also to ex-Marxists (many of whom participated in the symposium) [see Harootunian - Najita 1993: 760]. The criticism of Meiji era utilitarianism and state bureaucracy was inseparable from the denunciation of the international order dominated by the West. The overcoming of modernity for many thus meant the uprooting of capitalism and Western materialism and colonial power in Asia, together with a reidentification of Japanese ideals while reviving similar ideas in other Asian countries and recognizing the necessity of Japan's protection of East Asia [Harootunian - Najita 1993: 767]. The construction of a new ideal order that they all somehow vaguely pined for, however, could not be an outright rejection of the modern world. Instead it meant the building of an alternative Japanese or East Asian form of modernity that would overcome the faults of modernity imported from the West. This is so even if, as Hiromatsu writes, the symposium participants never clearly indicated what the alternative system replacing the old modernity or sublating its historical reality in social practice would be [Hiromatsu 1989: 199-200]. Eisenstadt's idea of

22 Hiromatsu [1989: 102]. The Shōwa Restoration movement was an anti-capitalist national reconstruction movement during the 1920 s and ' 30 s. The movement looked to some form of a post-Meiji revolution with the aim of overcoming the economic crisis and impasse of the political scene dominated by corrupt politicians. This culminated in a series of coups détat and assassination plots from 1930 to '36, involving Army officers, secret societies, and politicians. These plots were all crushed but the pressure led to greater military influence on the government. The movement was also related to an anti-Western colonialist and pan-Asianist sentiment that would idealize and postulate the cooperation among the peoples of East Asia, a "cooperative harmony of the five tribes” (五族協和) of Japanese, Han Chinese, Manchurians, Koreans, and Mongolians. 
multiple modernities and his theory of how modernizing societies develop has recently helped to refute the "homogenizing and hegemonic assumptions" of the Western program of modernity as found, for example, in Hegel's Philosophy of History [Eisenstadt 2000: 1]. Many movements within non-Western societies - various nationalist or traditionalist movements - that emerged from the mid-nineteenth century up to after World War II have articulated strong anti-Western, even anti-modern themes, and yet, Eisenstadt points out, were distinctively modern. We can count here Japan's program of modernization that developed, from its start in the Meiji period, into the wartime (WWII) rhetoric of resistance to Western imperialism, including the overcoming modernity discourses. On the other hand, however, counter to the hegemonic assumptions of the Japanese program of modernizing Asia, we probably also need to account for differences within Asia in the multiple ways of modernization, an issue that was not raised in the prewar and wartime discourse on modernity. ${ }^{23}$

Today U.S. hegemony is in decline as the world heads towards greater multi-polarity. In post-war Asia, Japan has again seized the economy of the East Asian sphere, and more recently so has China. The topic of "overcoming modernity" to that extent is still relevant [Karatani 1989: 272]. But to reiterate our point this would mean the construction of a new alternative modernity if it is not to mean an impossible return to ancient or medieval pre-modernity. I would agree with Hiromatsu that we need today to examine and reconsider, from the lens of contemporary concerns and historical contexts, the content of ideas expressed in the wartime discourse on overcoming modernity [Hiromatsu 1989: 224]. The difficulty is in clearly separating the fundamental issues from parts distorted by circumstances of the period - to not throw the baby out with the bathwater. There are still plenty of arguments, themes, and motifs reflected in the wartime discourse on overcoming modernity, such as the hermeneutical reassessment of nothingness from the Eastern tradition, the unity of global history and its recovery in accordance with a multi-polar dynamic to overcome the Eurocentric uni-linear view of world history, or the overcoming of the various dualisms of modern thought [see Hiromatsu 1989: 253-254]. To discuss these issues, we need to seriously engage and examine, especially, the philosophy of the Kyoto School anew.

The multipolarity of the world now revealed means, however, that we no longer need to uncritically adopt the dichotomization of the globe into the geographical hemispheres of East vs. West, as previously the Orientalists in the West, but also the symposium participants had done. We ought to recognize that, even if modernity originated in Europe, a multiplicity of modernities have arisen in a multipolar world along with a variety of cultural agendas in different modern societies. Eisenstadt claims that this diversity "attests to the continual development of multiple modernities, ... multiple interpretations of modernity, and ... to attempts at 'de-Westernization', depriving the West of its monopoly on modernity" [Eisenstadt 2000: 24]. What is called for today after the Cold War, after the fall of the Berlin Wall, after 9/11 and in the face of mounting tensions between the U.S., China, and Russia is the construction of a new pluralistic world order to contribute to the unfolding in world history of viable modernities, overcoming the faults of old models of modernity.

${ }^{23}$ This is the point Takeuchi makes in his essay "Asia as Method" [Takeuchi 2005b]. 


\section{Bibliography}

Barthes, Roland [1975]. The Pleasure of the Text. NYC: Hill \& Wang.

Calichman, Richard F. (ed. \& trans.) [2008]. Overcoming Modernity: Cultural Identity in Wartime Japan. NYC: Columbia University Press.

De Bary, Theodore - Gluck, Carol - Tiedermann, Arthur E. (eds.) [2005]. Sources of Japanese Tradition, 2nd Edition, Vol. Two: 1600 to 2000. NYC: Columbia University Press.

Eisenstadt, Shmuel N. [2000]. Multiple Modernities. Daedalus 129 (1): 1-29.

Fujita, Masakatsu [2018]. Nihon tetsugakushi [History of Japanese Philosophy]. Kyoto: Shōwadō.

Guénon, René [1996]. The Crisis of the Modern World. Ghent, NY: Sophia Perennis et Universalis.

Harootunian, H. D. - Najita, Tetsuo (eds.) [1993]. Japanese Revolt against the West: Political and Cultural criticism in the Twentieth Century. In. Duus, Peter (ed.). The Cambridge History of Japan, vol. 6. Cambridge: Cambridge University Press, pp. 711-174.

Hashikawa, Bunsō [1965]. Zōho Nihon romanha hihan josetsu [Critical Introduction to the Japanese Romantic School, Enlarged edition]. Tokyo: Miraisha.

Hashikawa, Bunsō [2000]. Hashikawa Bunsō sakushū [Hashikawa Bunsō Collected Works] vol. 1. Tokyo: Chikuma shobō.

Hiromatsu, Wataru [1989]. "Kindai no chōkoku" ron: Shōwa shisōshi he no isshikaku [On "Overcoming Modernity": A Perspective on the History of Shōwa Thought]. Tokyo: Kodansha.

Horio, Tsutomu [1994]. The Chūōkōron Disucssions: Their Background and Meaning. In. Heisig, James W. - Maraldo, John C. (eds.). Rude Awakenings: Zen, the Kyoto School, \& the Question of Nationalism. Honolulu: University of Hawai'i Press, pp. 289-315.

Josephson, Jason Ananda [2012]. Invention of Religion in Japan. Chicago: University of Chicago Press.

Karatani, Kōjin [1989]. Kaisetsu - Kindai no chōkoku nit suite ["Commentary: On Overcoming Modernity"]. In. Hiromatsu, Wataru. "Kindai no chōkoku" ron: Shōwa shisōshi he no isshikaku. Tokyo: Kodansha, pp. 263-272:

Karatani, Kōjin [2005]. Overcoming Modernity. In. Calichman, Richard F. (ed.). Contemporary Japanese Thought. NYC: Columbia University Press, pp. 101-118.

Kawakami, Tetsutarō - Takeuchi, Yoshimi (eds.) [1979]. Kindai no chōkoku [Overcoming Modernity]. Tokyo: Tomiyama-sho.

Kosaka, Kunitsugu [2018]. The Kyoto School and the Issue of "Overcoming Modernity". In. Fujita, Masakatsu (ed.). The Philosophy of the Kyoto School. Singapore: Springer.

Matsumoto Ken'ichi [1979]. Kaidai [Bibliographical Introduction]. In. Kawakami, Tetsutarō - Takeuchi, Yoshimi (eds.). Kindai no chōkoku [Overcoming Modernity]. Tokyo: Tomiyama-sho.

Miki, Kiyoshi [1967]. Miki Kiyoshi zenshū [Collected Works of Miki Kiyoshi] vol. 15. Tokyo: Iwanami shoten.

Miki, Kiyoshi [1986]. Miki Kiyoshi zenshū [Collected Works of Miki Kiyoshi] vol. 20. Tokyo: Iwanami shoten.

Minamoto, Ryōen [1994]. The Symposium on “Overcoming Modernity”. In. Heisig, James W. - Maraldo, John C. (eds.). Rude Awakenings: Zen, the Kyoto School, \& the Question of Nationalism. Honolulu: University of Hawai'i Press, pp. 197-229.

Parkes, Graham [1997]. The Putative Fascism of the Kyoto School and the Political. Philosophy East and West 47 (3): 305-336.

Spengler, Oswald [1961]. The Decline of the West. Oxford: Oxford University Press.

Takeuchi, Yoshimi [2005a]. Overcoming Modernity. In. Calichman, Richard F. (ed. \& trans.). What is Modernity? Writings of Takeuchi Yoshimi. NYC: Columbia University Press, pp. 103-147.

Takeuchi, Yoshimi [2005b]. Asia as Method. In. Calichman, Richard F. (ed. \& trans.). What is Modernity? Writings of Takeuchi Yoshimi. NYC: Columbia University Press, pp. 149-165.

Williams, David [2014]. The Philosophy of Japanese Wartime Resistance: A Reading with Commentary, of the Complete Texts of the Kyoto School Discussions of "The Standpoint of World History and Japan". London \& NYC: Routledge. 
Yasuda, Yojūrō [1985-89a]. Bunmei kaika no ronri no shūen [The End of the Logic of Civilization and Enlightenment]. In. Yasuda Yojūrō zenshū, vol. 7. Tokyo: Kodansha, pp. 11-21.

Yasuda, Yojūrō [1985-89b]. Manshūkoku kōtei hata ni sasageru kyoku [A Song Dedicated to the Flag of the Emperor of Manchukuo]. In. Yasuda Yojūrō zenshū, vol. 11. Tokyo: Kodansha, pp. 105-106.

John W. M. Krummel is Associate Professor in Religious Studies at Hobart and William Smith Colleges; Assistant Editor of The Journal of Japanese Philosophy; Editor of Social Imaginaries; and President of the International Association for Japanese Philosophy. He is the author of Nishida Kitarōs Chiasmatic Chorology: Place of Dialectic, Dialectic of Place (Indiana University Press). His writings on various topics have appeared in a variety of journals and books. He has translated several works, including Place and Dialectic: Two Essays by Nishida Kitarō (Oxford); and is editor and main translator of Contemporary Japanese Philosophy: A Reader (Rowman and Littlefield International). 